Original Paper

\title{
Upaya Meningkatkan Hasil Belajar Siswa Kelas XI IPS pada Materi Turunan Fungsi Aljabar dengan Metode Tutor Sebaya
}

\author{
Nuraini $\mathbf{1}^{*}$ \\ ${ }^{1}$ Sekolah Menengah Atas Negeri 1 Mataram, Kota Mataram, Nusa Tenggara Barat, Indonesia
}

*Corresponding Author:

Nuraini, Sekolah

Menengah Atas Negeri 1

Mataram, Kota Mataram,

Nusa Tenggara Barat,

Indonesia

Email:

nurainimajid31@gmail.com

\begin{abstract}
Abstrak: Tujuan penelitian ini adalah untuk mengetahui peningkatan hasil belajar siswa kelas XI IPS pada materi turunan fungsi aljabar dengan menerapkan metode tutor sebaya di SMA Negeri 1 Mataram tahun pembelajaran 2018/2019. Data penelitian diperoleh melalui observasi, dokumentasi, dan wawancara. Observasi dilakukan dalam pembelajaran dengan model siklus yang menerapkan metode tutor sebaya, dokumentasi mempelajari dokumen hasil pembelajaran, sedangkan wawancara dilakukan dengan guru dan siswa. Analisis data dilakukan pada data awal yaitu prasiklus, data hasil observasi, dan data akhir hasil penilaian. Berdasarkan analisis data disimpulkan bahwa telah terjadi peningkatan hasil belajar siswa kelas XI IPS pada materi turunan fungsi aljabar dengan menerapkan metode tutor sebaya di SMA Negeri 1 Mataram tahun pembelajaran 2018/2019. Hal ini ditandai dengan peningkatan nilai rata-rata, yaitu 70,88 pada siklus I, dan 84.53 pada siklus II..
\end{abstract}

Kata kunci: Tutor sebaya; Turunan fungsi aljabar; Siklus Hasil belajar.

\section{Pendahuluan}

Matematika merupakan mata pelajaran yang penting bukan hanya berkaitan dengan mata pelajaran itu sendiri melainkan juga untuk sebagian besar ilmu-ilmu yang lain (Hudojo, 1988). Menurut Majer (1996) matematika lebih sedikit mengenai benda namun lebih banyak mengenai cara memperhatikan dan memahami. Manfaat mempelajari matematika tersebut memang dimungkinkan karena seperti yang dikemukakan oleh Cornelius, matematika merupakan sarana berpikir logis, membantu memecahkan masalah sehari-hari, mengenal pola-pola hubungan generalisasi pengalaman, sarana mengembangkan kreativitas, dan sarana meningkatkan kesadaran terhadap perkembangan budaya (dalam Abdurrohman, 1999). Memperhatikan pentingnya matematika maka perlu adanya peningkatan mutu pendidikan matematika. Salah satu hal yang harus diperhatikan adalah peningkatan prestasi belajar matematika siswa di sekolah.

Matematika merupakan salah satu mata pelajaran yang masih dianggap sulit dan tidak menarik bagi banyak siswa (Siregar, 2017). Oleh karena itu, dalam pembelajaran matematika diperlukan metode mengajar yang bervariasi. Artinya tidak semua pokok bahasan atau setiap KD menggunakan metode yang sama. Karena metode pada KD tertentu 
belum tentu cocok dengan pokok bahasan/KD yang lain. Kenyataan yang terjadi adalah penguasaan siswa terhadap materi matematika tergolong rendah dibandingkan dengan mata pelajaran lain.

Kesulitan belajar matematika seperti yang dikemukakan di atas juga terjadi pada SMAN 1 Mataram penguasaan materi matematika oleh siswa masih ada yang belum memenuhi KKM. Salah satu materi matematika yang penguasaannnya rendah adalah pada KD turunan fungsi khususnya "turunan fungsi aljabar" pada siswa kelas XI IPS 1. Pada materi tersebut banyak siswa pada tahun sebelumnya yang belum mampu menyelesaikan soal dengan baik, hal ini dapat dilihat dari rata - rata hasil belajar matematika kelas XI IPS sebelumnya pada meteri turunan fungsi aljabar hanya $56 \%$ dengan kriteria ketuntasan minimal (KKM) 80 pada skala 0 100.

Pengalaman penulis mengajarkan materi turunan fungsi aljabar pada kelas XI IPS yang menggunakan metode ceramah dan penugasan pada umumnya merupakan pembelajaran yang tertumpu pada guru. Artinya, siswa kurang dapat mengembangkan kemampuannya dalam pembelajaran turunan fungsi aljabar. Hal ini teridentifikasi disebabkan beberapa hal, yaitu: materi turunan adalah materi yang diajarkan di kelas XI dan tidak ada keterkaitan antara materi tersebut dengan materi di kelas sebelumnya, siswa kurang fokus ada materi yang diajarkan, adanya kesan pada siswa bahwa mempelajari materi ini tidak berhubungan langsung dengan jurusan mereka dan pengaplikasian dalam kehidupan sehari-hari, alokasi waktu yang sedikit untuk materi turunan fungsi aljabar, dan siswa masih pasif menerima informasi pengetahuan dan keterampilan.

Berkaitan dengan kondisi di atas, dibutuhkan alternatif pemecahan masalah untuk perbaikan pembelajaran. Alternatif yang dipilih adalah dengan menerapkan pembelajaran tutor sebaya karena seperti yang dikemukakan Harsanto (2007) dan Djamarah
(2010) tutor sebaya dapat meningkatkan keaktifan siswa dalam belajar.

\section{Metode}

Penelitian ini menerapkan langkahlangkah Penelitian Tindakan Kelas yang meliputi tahap (1) perencanaan, (2) tindakan, (3) observasi, dan (4) refleksi. Tahapan tersebut diterapkan dalam siklus sampai terpenuhinya indikator keberhasilan penelitian. Metode pembelajaran yang dilaksanakan adalah tutor sebaya. Tutor dipilih sesuai dengan kriteria tutor menurut Arikunto (1988).

Sumber data penelitian adalah guru dan siswa. Pengumpulan data dilakukan dengan metode observasi, dokumentasi, dan wawancara. Observasi dilakukan pada saat pembelajaran, dokumentasi dilakukan dengan mencermati dokumen hasil belajar atau hasil tes siswa, sedangkan wawancara dilakukan untuk memperoleh informasi langsung dari guru dan siswa.

Data yang diperoeh dianalisis untuk mengetahui atau memastikan bahwa dengan metode tutor sebaya dapat meningkatkan keaktifan dan hasil belajar peserta didik pada materi turunan fungsi aljabar di kelas XI IPS I SMA Negeri 1 Mataram. Analisis data mengikuti pendapat Nasution (1996) yaitu alaisis kualitatif harus dimulai dari awal, dituangkan dalam tulisan, dan dianalisis. Langkah-langkah analisis data adalah sebagai berikut. (1) Analisis data awal yaitu data hasil belajar prasiklus. Data hasil belajar yang diperoleh berdasarkan tes uji kompetensi dalam bentuk soal objektif menggunakan skala 0-100 kemudian dianalisis dengan menggunakan rata-rata dan ketutasan belajar. (2) Data hasil observasi yang dianalisis secara deksriptif kualitatif (Nawawi, \& Martini, 1996), menggunakan uji beda (uji komparasi). Komparasi dilakukan atas hasil belajar metode awal (ceramah) dengan metode tutor sebaya. (3) Analisis data akhir, yakni data dari 
siklus I dan II. Berikut ini adalah rumus rumus yang digunakan.

a) Rata - rata setiap aspek penilaian (rata rata klasikal)

$$
\bar{x}=\frac{\bar{x}_{A}+\bar{x}_{1}}{N}
$$

Keterangan :

$\bar{x}=$ Rata - rata beda nilai antara kondisi awal dengan metode tutor sebaya

$\bar{x}_{A}=$ Rata - rata nilai kondisi awal

$\bar{x}_{T}=$ Rata - rata nilai tutor sebaya

$\mathrm{N}$ = Banyak data

b) Rumus yang digunakan untuk mengetahui penyebaran nilai terhadap rata - ratanya

$$
S D=\sqrt{\frac{\sum(x-\bar{x})^{2}}{n-1}}
$$

Keterangan :

$\mathrm{SD}=$ Standar Deviasi (Simpangan baku)

$\mathrm{X}=$ Nilai dari data ke-i $\bar{x}=$ Rataan hitung dari data

$\mathrm{N}=$ Banyak siswa

c) Rumus akhir untuk mengetahui beda hasil metode tutor sebaya adalah

$$
T_{s}=\frac{\bar{X}}{\frac{S D}{\sqrt{n}}}
$$

Keterangan :

$T_{s} \quad=$ Rumus akhir tutor sebaya

$\bar{x} \quad=$ Rataan hitung dari data

$\mathrm{SD}=$ Standar Deviasi (Simpangan baku)

$\mathrm{N}$ = Banyak siswa

\section{Hasil dan Pembahasan}

Hasil penelitian ini dapat dilihat pada Tabel 1, 2, 3 dan 4 .

Tabel 1: Hasil Observasi Aktivitas Siswa Siklus I

\begin{tabular}{lllll}
\hline No & Kegiatan & Siswa Aktif & Siswa Tidak Aktif & $\%$ aktif \\
\hline 1 & Mendengarkan penjelasan guru & 22 & 12 & $64.70 \%$ \\
2 & Memperhatikan penjelasan tutor sebaya & 24 & 10 & $70,59 \%$ \\
3 & Keaktifan mengajukan pertanyaan & 17 & 17 & $50 \%$ \\
4 & Tutor maksimal menjalankan tugas & 5 & 2 & $71 \%$ \\
5 & Mencatat materi & 26 & 8 & $76,47 \%$ \\
6 & Aktif menjawab pertanyaan dalam LKPD & 24 & 10 & $70,9 \%$ \\
\hline
\end{tabular}

Tabel 2: Hasil Observasi Aktivitas Siswa Siklus II

\begin{tabular}{lllll}
\hline No & Kegiatan & Jumlah Aktif & Jumlah Tidak Aktif & \% aktif \\
\hline 1 & Mendengarkan penjelasan guru & 27 & 7 & $79.41 \%$ \\
2 & Memperhatikan penjelasan tutor sebaya & 30 & 4 & $88,23 \%$ \\
3 & Keaktifan mengajukan pertanyaan & 23 & 11 & $67,64 \%$ \\
4 & Tutor maksimal menjalankan tugas & 7 & 0 & $100 \%$ \\
5 & Mencatat materi & 32 & 2 & $94,12 \%$ \\
6 & Aktif menjawab pertanyaan dalam LKPD & 32 & 2 & $94,12 \%$ \\
\hline
\end{tabular}

Tabel 3: Ketuntasan Belajar Siswa

\begin{tabular}{llllll}
\hline \multirow{2}{*}{ No } & \multirow{2}{*}{ Nama } & \multicolumn{2}{l}{ Nilai dan Ketuntasan } \\
\cline { 3 - 6 } & & Siklus I & Siklus II & \\
\hline 1 & Afif Aufa Rifqi & 50 & Tidak Tuntas & 71 & Tuntas \\
2 & Afifah Jilan MHM & 90 & Tuntas & 95 & Tuntas \\
3 & Ahmad Ricky B & 90 & Tuntas & 90 & Tuntas \\
4 & Akhmad Dani & 89 & Tuntas & 92 & Tuntas \\
5 & Alexandro Gustavo & 65 & Tidak Tuntas & 80 & Tuntas \\
6 & Al-Fath Duta Arditia & 65 & Tidak Tuntas & 85 & Tuntas \\
\hline
\end{tabular}




\begin{tabular}{|c|c|c|c|c|c|}
\hline \multirow{2}{*}{ No } & \multirow{2}{*}{ Nama } & \multicolumn{4}{|c|}{ Nilai dan Ketuntasan } \\
\hline & & \multicolumn{2}{|c|}{ Siklus I } & \multicolumn{2}{|c|}{ Siklus II } \\
\hline 7 & Alifaldo Satiyaki H & 88 & Tuntas & 90 & Tuntas \\
\hline 8 & Baiq Amalia Asri A & 70 & Tidak Tuntas & 85 & Tuntas \\
\hline 9 & Baiq Risya Desfiarni & 80 & Tuntas & 90 & Tuntas \\
\hline 10 & Claudia Adiella U & 80 & Tuntas & 85 & Tuntas \\
\hline 11 & Dewa Bagus Yoga P & 80 & Tuntas & 86 & Tuntas \\
\hline 12 & Dewa Dipta P & 80 & Tuntas & 86 & Tuntas \\
\hline 13 & Fadhila Humaira S & 65 & Tidak Tuntas & 86 & Tuntas \\
\hline 14 & Gde Abhie Yudisthira & 70 & Tidak Tuntas & 86 & Tuntas \\
\hline 15 & Gede Dody V S & 50 & Tidak Tuntas & 85 & Tuntas \\
\hline 16 & Geraldo Erik M & 60 & Tidak Tuntas & 83 & Tuntas \\
\hline 17 & Gusti Ayu Sinta J & 80 & Tuntas & 85 & Tuntas \\
\hline 18 & Ifal Ramadhan P & 50 & Tidak Tuntas & 80 & Tuntas \\
\hline 19 & Janieta Angel P L & 88 & Tuntas & 88 & Tuntas \\
\hline 20 & Kayla Azzalia & 65 & Tidak Tuntas & 84 & Tuntas \\
\hline 21 & L Mohammad K H H & 80 & Tuntas & 85 & Tuntas \\
\hline 22 & L Muhamad Naufal R & 50 & Tidak Tuntas & 88 & Tuntas \\
\hline 23 & Lara Ayu Oktaviani & 80 & Tuntas & 90 & Tuntas \\
\hline 24 & Marsa Rabbani Hasya & 50 & Tidak Tuntas & 80 & Tuntas \\
\hline 25 & Muhammad Asfian M & 50 & Tidak Tuntas & 68 & Tidak Tuntas \\
\hline 26 & M Ariq Mulya R & 45 & Tidak Tuntas & 70 & Tidak Tuntas \\
\hline 27 & Nadya Safira A & 90 & Tuntas & 92 & Tuntas \\
\hline 28 & Perdana Wangsa Putri & 80 & Tuntas & 94 & Tuntas \\
\hline 29 & Rifqy Novandi P F & 40 & Tidak Tuntas & 72 & Tidak Tuntas \\
\hline 30 & Syarifa Noviana & 65 & Tidak Tuntas & 85 & Tuntas \\
\hline 31 & Tiara Amelia Putri & 80 & Tuntas & 80 & Tuntas \\
\hline 32 & Tiara Jasmine & 80 & Tuntas & 83 & Tuntas \\
\hline 33 & Yasmine Raudhani & 80 & Tuntas & 85 & Tuntas \\
\hline 34 & Zidan Akbar & 85 & Tuntas & 90 & Tuntas \\
\hline
\end{tabular}

Tabel 4: Rerata Nilai dan \% Ketuntasan

\begin{tabular}{llc}
\hline Siklus & Rerata & Persentase Ketuntasan \\
\hline I & 70,88 & $53 \%$ \\
II & 84,53 & $88 \%$ \\
\hline
\end{tabular}

Analisis hasil observasi siklus I masih menunjukkan hasil belajar siklus I hanya mencapai ketuntasan klasikal 53\%, yaitu baru 18 dari 34 siswa yang tuntas. Dari hasil diskusi dengan observer dan hasil tes diketahui bahwa hasil yang masih rendah tersebut disebabkan terutama kelemahan pada saat pelaksanaan pembelajaran. Kelemahan pelaksanaan pembelajaran berkaitan dengan aspek guru dan aspek siswa. Dari aspek guru, guru masih belum bisa memberikan motivasi dengan baik dan belum bisa mengefektifkan waktu sehingga pada akhir pembelajaran guru lupa memberikan penguatan materi. Sedangkan dari siswa, data menunjukkan siswa yang mendengarkan penjelasan guru baru 22 orang, siswa yang memperhatikan penjelasan tutor sebaya baru 24 orang, keaktifan mengajukan pertanyaan dilakukan oleh 17 siswa, tutor yang maksimal menjalankan tugasnya baru 5 dari 7 orang, siswa yang mencatat materi ada 26 orang, dan siswa yang aktif menjawab pertanyaan dalam LKPD adalah 24 orang. Secara umum, dalam siklus I masih ada siswa yang belum memanfaatkan tutornya untuk bertanya, ada siswa bertanya pada tutor kelompok lain, dan siswa ada menanyakan jawaban LKPD pada siswa di kelompok lain. Analisis juga menunjukkan bahwa kelemahan utama siswa adalah pada penerapan rumusrumus fungsi turunan aljabar. Karena rumus 
turunan fungsi aljabar itu banyak, siswa merasa kesulitan memahami langkah-langkah penerapan rumus tersebut. Kesulitan tersebut karena faktor tutor dan siswa. Dari aspek tutor, kesiapan dari tutor juga masih dirasakan kurang karena tidak semua siswa yang menjadi tutor terbiasa menyampaikan materi kepada orang lain atau temannya. Ada indikasi bahwa kondisi ini terjadi karena menjadi tutor merupakan pengalaman pertama mereka. Dari aspek siswa yang bukan tutor, mereka masih ragu terhadap penjelasan temannya yang menjadi tutor.

Berdasarkan hasil refleksi siklus I dilakukan perbaikan atau perubahan yang dilakukan pada Siklus II, baik dari perencanaan maupun pelaksanaan. Dari segi perencanaan, perubahan yang dilakukan terutama dalam hal penyiapan kembali tutor dalam bentuk bimbingan oleh guru. Tutor yang semula masih malu dan belum terbiasa memberikan penjelasan kepada temannya, diarahkan, dimotivasi, dan dibimbing agar mereka memiliki kepercayaan diri yang lebih tinggi. Di samping itu, penyiapan kelompok juga dilakukan dengan lebih baik. Siswa yang bukan tutor dimotivasi untuk lebih sungguhsungguh dan memercayai kemampuan teman yang menjadi tutornya.

Dari aspek pelaksanaan pembelajaran, perbaikan dilakukan dengan menerapkan perbaikan perencanaan. Hasil bimbingan tersebut tutor menunjukkan bahwa pada pertemuan siklus II tutor sudah semakin siap. Siswa yang bukan tutor yang semula masih enggan untuk bertanya atau berlatih dengan tutor sudah semakin aktif. Siswa juga semakin percaya pada kemampuan dan penjelasan temannya yang bertindak sebagai tutor. Siswa semakin memiliki pengalaman untuk diskusi kelompok dengan teman tutor sebayanya sehingga hal-hal yang kurang pada siklus I hampir tidak muncul pada siklus II. Perhatian peserta didik pada teman tutor sebayanya ada peningkatan dan sudah lebih banyak siswa yang berani bertanya pada temannya. Hal itu terlihat dari peningkatan jumlah keaktifan siswa. Jumlah siswa yang mendengarkan penjelasan guru meningkat menjadi 27 orang, siswa yang memperhatikan penjelasan tutor sebaya 30 orang, keaktifan mengajukan pertanyaan dilakukan oleh 23 siswa, semua tutor (7 orang) sudah maksimal menjalankan tugasnya, siswa yang mencatat materi ada 32 orang, dan siswa yang aktif menjawab pertanyaan dalam LKPD adalah 32 orang. Perubahan-perubahan tersebut berpengaruh terhadap hasil belajar siklus II yang mencapai ketuntasan klasikal $88 \%$, yaitu 30 dari 34 siswa yang tuntas.

Hasil observasi proses pembelajaran dengan metode tutorial teman sebaya yang diterapkan pada siswa kelas XI IPS 1 SMAN 1 Mataram siklus I menunjukkan bahwa langkah-langkah pembelajaran dalam RPP secara umum dapat terlaksana, namun masih terdapat beberapa kendala atau kelemahan dalam penerapan dan pelaksanaan rencana pembelajaran yang juga berpengaruh pada hasil belajar siswa. Kelemahan tersebut diperbaiki dalam perencanaan dan pelaksanaan Siklus II. Kriteria-kriteria yang ditetapkan berkaitan dengan tutor juga secara umum telah terpenuhi sehingga dilihat dari sisi tutorial, tutorial telah berjalan dengan baik karena tutor dapat menjalankan perannya, anggota yang menerima dan memberikan respon pembelajaran serta suasana pembelajaran lebih kondusif. Artinya, kelemahan tutorial pada siklus I telah diperbaiki pada siklus II.

\section{Kesimpulan}

Berdasarkan hasil penelitian dapat disimpulkan bahwa terjadi peningkatan hasil belajar siswa kelas XI IPS pada materi turunan fungsi aljabar dengan menerapkan metode tutor sebaya di SMA Negeri 1 Mataram tahun pembelajaran 2018/2019. Hal ini ditandai dengan peningkatan prestasi belajar siswa dalam setiap siklus, yaitu siklus I nilai ratarata 70,88 atau hanya mencapai 53\% 
ketuntasan klasikal, siklus II nilai rata-rata 84,53 atau mencapai 88\% ketuntasan klasikal.

\section{Daftar Pustaka}

Abdurrohman, M. (1999). Pendidikan bagi Anak Berkesulitan Belajar. Jakarta: Rineka Cipta

Arikunto, S. (1988). Pengelolaan Siswa E Kelas (Sebuah Pendekatan Evaluatif). Jakarta: Rajawali.

Djamarah, S.B. (2010). Guru dan Anak Didik dalam Interaktif Edukatif: Suatu Pendekatan Teoritis Psikologis. Jakarta: Rineka Cipta.

Harsanto, R. (2007). Pengelolaan Kelas yang Dinamis. Yogyakarta: Kanisius.

Hudojo, H. (1988). Mengajar Matematika.
Jakarta: Delia Press.

Majer, H. (1996). Belajar dan Pembelajaran Matematika. Malang: Raja Grafindo Persada.

Nasution, S. (1996). Metode Penelitian Naturalistik Kualitatif. Bandung: Tarsito.

Nawawi, H. Martini, H. (1996). Penelitian Terapan. Yogyakarta: Gadjah Mada University Press.

Siregar, N. R. (2017). Persepsi Siswa pada Pelajaran Matematika: Studi Pendahuluan pada Siswa yang Menyenangi Game. Makalah Temu Ilmiah X Ikatan Psikologi Perkembangan Indonesi, Universitas gajah Mada. Tidak dipublikasikan. 